\title{
The Effect of Profitability and Company Size on Equity Structure of Pharmaceutical Company Listed on Idx Period 2012 -2017
}

\author{
$1^{\text {st }}$ Agung Fajar Ilmiyono ${ }^{1}, 2^{\text {nd }}$ Mutiara Puspa Widyowati $^{2}$ \\ \{agung.fajar@unpak.ac.id ${ }^{1}$, mutiara.puspa.widyowati@unpak.ac.id ${ }^{2}$ \}
}

Program Studi Akuntansi Fakultas Ekonomi Universitas Pakuan ${ }^{1,2}$

\begin{abstract}
To carry out its operational activities, the company requires funds. Funds can come from internal or external sources. If internal funds are not able to meet the company's funding needs, then the company must use external funds from the company, for example, debt. The capital structure shows the level of debt usage against the company's shareholders' equity. The high or low capital structure can be influenced by the profitability and firm size. Purpose of this research are for examine and analysis effect of profitability and firm size to capital structure in pharmaceutical sub-sector companies that listed on the Indonesia Stock Exchange for the period 2012-2017. The sample used in this research amounted to 6 companies using multiple linear regression analysis techniques. The result showed that profitability has a negative effect on capital structure, firm size has a negative effect on capital structure, and simultaneously the profitability and firm size influences the capital structure.
\end{abstract}

Keywords: Profitability, Company Size, and Capital Structure.

\section{Introduction}

In carrying out its activities, a company needs fund that determined by its operational activities. These funds can be sourced from internal and external. If the company prioritize internal source so ot will be reduce dependency with external parties. But if internal funds are considered already no longer able to meet funding needs company, then the company have to take external source of fund. External fund can be sourced from debt financing or external equity financing. One of the problem in financing policy is about the equity structure. So that it is important for the company to determine the source of equity for funding their operational activities.

Equity strucure is the ratio of debt (foreign equity) and owner's equity (Halim, 2015:81). Equity structure can be measured by Debt to equity ratio (DER). DER is the ratio of debt level to total shareholder equity (Wijaya, 2011:101). DER is the important ratio to asses financial company health. If the ratio is higher means that company is funded by creditor or debt funded. The creditor and investor usually choose company with lower DER. Lower DER means that the interest of creditor and investor are more protected if there is a decline in business. Thus, companies that have a high Debt to Equity Ratio may not be able to withdraw additional capital with loans from other parties. 
Riyanto (2013: 296) states that capital structure is an important problem for every company, because bad capital structure will have a direct effect on the company's financial position. A good capital structure is a capital structure that optimizes the balance between risk and return thus maximizing stock prices. Companies that have bad capital structure, where there is a gap between the available capital and the capital needed will result in companies using external funding through debt that will burden the company.

Capital structure is influenced by several factors such as profitability, company size, asset structure, company liquidity, company growth, tax rate, business risk, operating leverage, management attitude, financial flexibility and so on (Hadianto dalam Hidayat, 2015). Profitability is one of the factors that influence the capital structure by showing the company's ability to generate profits for a certain period (Munawir 2014:33). Brigham and Houston (2013: 189) state that high returns allow companies to do most of their funding through funds generated internally. Companies with high profitability have more internal funds than companies with low profitability.

Profitability in relation to capital structure has an influence where companies that have high profitability will reduce their dependence on outsiders because the high level of profit allows the company to obtain the majority of its funding from retained earnings. This is in line with the Pecking Order Theory (Myers \& Majluf, 1984) that companies tend to use as many internal funding sources as possible before deciding to owe.

Company size is an important factor which is a consideration in making decisions related to capital structure. Riyanto (2013: 299) states that the size of the company influences the capital structure. The larger the size of a company will tend to use a larger debt. This happens because creditors are more interested in large companies than small companies because loans from creditors require guarantees that are worth the amount lent to the company.

This study examines the pharmaceutical sub-sector companies in the period 2012-2017, where there are gaps or gaps between existing theories and practice.

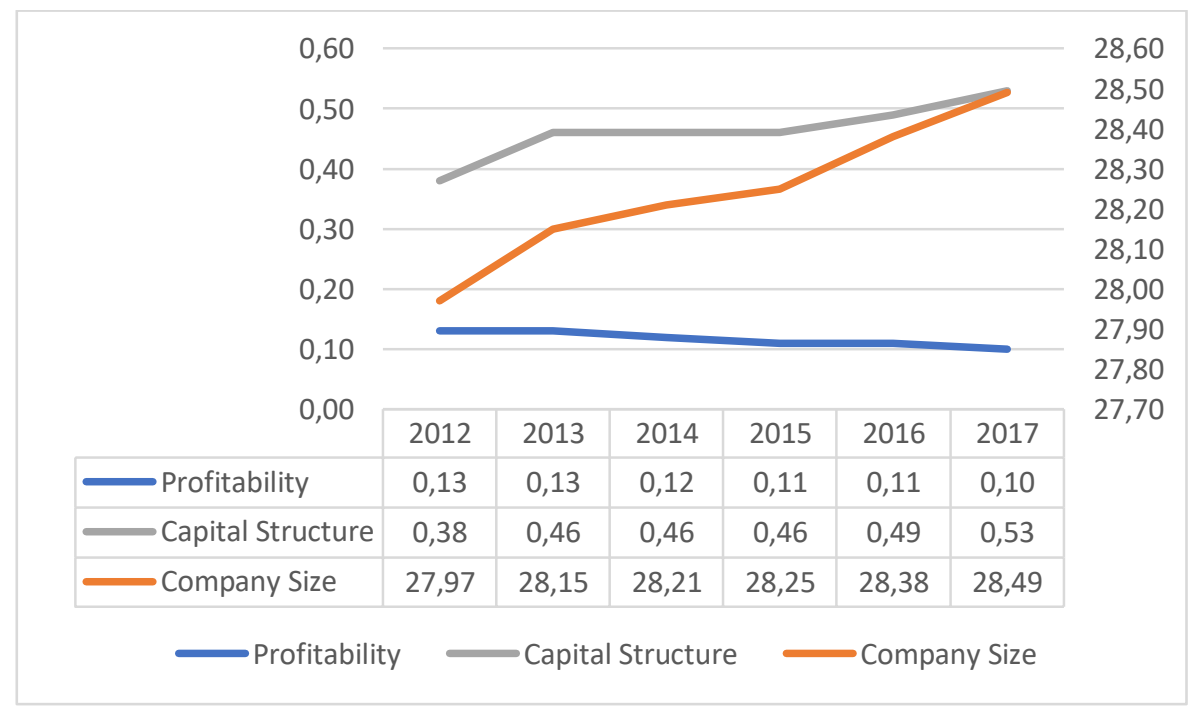

Figure 1. Graphic of Average Profitability, Company Size, and Capital Structure of Pharmaceutical Companies Registered on the Stock Exchange for the 2012-2017 
Research conducted by Tasman and Melda (2015) found that profitability had a negative and significant effect on capital structure. However, from Figure 1 it can be seen the gap between the theory and the phenomenon that occurred for 4 years, that the value of low profitability is not always accompanied by a high value of capital structure. As happened in 2013 when the value of profitability did not change from the previous year, the capital structure actually increased by 0.08 . In 2014 where the value of profitability decreased by 0.01 , the capital structure did not change in value from the previous year, so did the case in 2015 where profitability experienced a decline in value but the capital structure did not change.

Then in 2016 where the value of profitability remained 0.11 but the capital structure increased by 0.03 . Research conducted by Maidah (2016) states that company size has a positive and significant influence on capital structure, whereas in the graph it appears that there are differences between the theory and the phenomenon for 2 years. In 2014 when the size of the company increased by 0.06 , its capital structure did not change from the previous year. Then in the following year, namely 2015 the size of the company also increased from the previous year by 0.04 while the capital structure did not experience an increase or decrease.

Because there are inconsistencies between the results of previous studies, the researchers are interested in researching and further examining the effect of company profitability and size on the company's capital structure.

\section{Study Of Theory And Literature}

\subsection{Pecking Order Theory}

The Pecking Order Theory proposed by (Myers \& Majluf, 1984) states that companies tend to use as many internal funding sources as possible before deciding to owe. This theory described that:

1. the company likes internal financing (funding from the results of the company's operations).

2. If external financing is needed, the company will issue the safest securities first, that is, starting withcharacterized by options (such as convertible bonds), only when there is still insufficient, new shares are issued.

3. The company tries to adjust the targeted dividend distribution ratio, by trying to avoid changes in dividend payments drastically.

4. Relatively reluctant dividend policies to be changed, along with unpredictable fluctuations in profitability and investment opportunities, result in sometimes operating funds sometimes exceeding funding requirements for investment.

\subsection{Profitability}

Kasmir (2016: 196) defines that profitability ratios are ratios to assess a company's ability to seek profits or profits in a given period. This ratio also provides a measure of the level of effectiveness of a company's management as indicated by profits generated from sales or from investment income. Fitriati and Handayani (2016) in their study said that profitability is the company's ability to obtain profits from its operations. Whereas Agustini and Budiyanto (2015) in their research stated that profitability is the company's ability to earn profits from the business activities they do. 
Profitability has several types of ratios that can be used to review a company's ability to generate profits, including Return on Assets (ROA), Return on Equity (ROE), Earning Per Share (EPS), Profit Margin (Profit Margin on Sale), Profit Margin Gross (Gross Profit Margin), and Net Profit Margin [Kasmir (2016: 201) and Sartono (2010) in Fahmi (2013: 135)]. In this study profitability is measured using the Return on Asset ratio. Rerun On Asset (ROA) is a ratio that shows the return (return) on the amount of assets used in the company. According to Kasmir (2014: 201), ROA can be calculated using the following formula:

$$
R O A=\frac{\text { Net profit after tax }}{\text { Total Assets }}
$$

\subsection{Company Size}

Company size is an important factor which is a consideration in making decisions related to capital structure. Company size can affect the capital structure because the larger the size of a company will tend to use larger debt. Debt is one source of funds chosen if the company's own capital is insufficient. According to Kurniasih, Butar and Sudarsi (2012), company size is a value that shows the size of the company. Then according to Riyanto (2008: 313) in Hartati (2015) states that the size of the company is seen from the magnitude of the value of equity, the value of sales or asset value. Whereas Meisya (2017) defines company size as a measure or size of assets owned by a company.

The formula used to measure company size using total assets is as follows:

Information:

$$
\text { SIZE }=\text { Ln (Total Assets) }
$$

Ln = Natural logarithms

The total assets are transformed into natural logarithms (ln) because the total assets are relatively large compared to other variables. In this way the variance between variables is not too large (Kurnianingsih, 2013).

\subsection{Capital Structure}

Capital structure plays an important role in a company's activities. Capital structure is obtained from sources of funds from within the company and from outside the company. According to Brigham and Houston (2006: 42) in Antoni, et al. (2016), there are several factors that influence the company's capital structure decisions, including: sales stability, asset structure, operating leverage, growth rate, profitability, company size, tax, control, management attitude, lender attitude and rating agent, conditions market and internal conditions of the company, as well as financial flexibility.

Halim (2015: 81) defines that capital structure is the ratio between debt (foreign capital) and equity (equity). According to Isnurhadi and Ferdiansyah (2013), capital structure is a proposition in determining the fulfillment of corporate expenditure needs where funds are obtained using a combination or source of sources derived from long-term funds consisting of two main sources, namely those originating from inside and outside the company. Whereas According to Cahyo, et al. (2014), the capital structure is the comparison or balance between foreign capital and own capital. Foreign capital in this case can be in the form of long-term debt and short-term debt.

To be able to obtain an overview of the financial condition of a company, it is necessary to analyze or interpret the financial statements that contain the financial data of the company 
concerned. According to Sjahrial and Purba (2013: 37) the capital structure ratio consists of: Total Debt to Total Assets Ratio / DAR, Total Debt to Equity Ratio / DER, and Long Term Debt to Equity Ratio / LDER. In This study researchers used Debt to Equity Ratio (DER) to measure the value of the company's capital structure. DER is the ratio between total debt and total equity.

$$
D E R=\frac{\text { Total Liability }}{\text { Total Equity }}
$$

\section{Hypothesis Development}

Profitability or ability to earn profits shows the company's ability to generate profits during certain periods of Munawir (2014: 33). According to Pecking Order Theory, companies tend to use as many internal funding sources as possible before deciding to owe (Myers \& Majluf, 1984 in Sugiarto, 2009). According to the theory of Weston and Brigham (1990) that companies with levels a high return on investment uses a relatively small debt due to the level high returns allow companies to finance most internal funding. This is in line with research conducted by Rahmiati, Tasman, and Melda (2015) and Nadzirah, Yudiaatmaja and Cipta (2016) that profitability has a negative and significant effect on capital structure.

\section{$H_{1}$ : Profitability has a negative effect of on capital structure}

Company size is the size or size of assets owned by the company (Meisya, 2017). The size of a company will affect the capital structure, the greater the company, the greater the funds needed by the company to invest (Ariyanto, 2002 in Yunita Widyaningrum, 2015). According to Riyanto (2011: 230) the size of the company size directly affects the capital structure policy. This is in line with the research conducted by Maidah (2016) and Juliantika and Dewi (2016) that company size has a positive and significant effect on capital structure.

\section{$\mathrm{H}_{2}$ : Company size influences positive capital structure}

Achmad and Triyonowati (2017) state that a high rate of return makes it possible to finance most of the funding needs with funds generated internally. This shows that profitability affects the company capital structure. The higher the profit obtained means the lower the debt issued. In addition, he also stated that the greater the size of a company, the greater the tendency to use foreign capital. This is in line with the research conducted by Nadzirah, Yudiaatmaja and Cipta (2016) that the profitability and size of the company influence the capital structure.

\section{$\mathrm{H}_{3}$ : Profitability and company size jointly effect capital structure}

\section{Research Methods}

Population in this study are pharmaceutical sub-sector companies listed on the Indonesia Stock Exchange for the period 2012-2017. Sampling was done by purposive sampling method, 
from a population of 10 companies after sampling selection, which became the sample of the study were as many as 6 companies.

Data used is quantitative and secondary data in the form of company financial statements downloaded from the Indonesia Stock Exchange website and the IDN Financials website sampled. This study also uses panel data. This study uses independent variables namely Profitability and Company Size while the dependent variable is Capital Structure. The analysis used in this study uses quantitative analysis, in the form of testing hypotheses using statistical tests. Quantitative analysis is emphasized to reveal the behavior of research variables. The researcher conducted a classic assumption test and then used multiple linear regression analysis as follows:

$\mathrm{Y}=\mathrm{a}+\mathrm{b}_{1} \mathrm{X}_{1 \mathrm{it}}+\mathrm{b}_{2} \mathrm{X}_{2 \mathrm{it}}+\mu_{\mathrm{it}}$

Information:

$\mathrm{Y}=$ Capital Structure / Debt to Equity Ratio (DER)

$\mathrm{a}=$ Constant

$\mathrm{b}=$ Regression Coefficient

$\mathrm{X} 1=$ Profitability / Return on Asset 0. (ROA)

$\mathrm{X} 2$ = Company Size

$\mu=$ Disturbance error $\mathrm{i}$ : $\mathrm{i}$ i individual

$\mathrm{t}=$ period

This study also uses hypothesis testing including the coefficient of determination, $\mathrm{t}$ test, and $\mathrm{F}$ test.

\section{Results}

\section{Hypothesis testing}

\section{Coefficient of Determination}

Based on the test results of the coefficient of determination test in this study the results obtained that the value of Adjusted R Square is 0.619. This means that $62 \%$ of capital structure variables can be explained by profitability and firm size variables while the remaining $38 \%$ is explained by other variables not included in this study. 
Uji t

Table 1. $t$ Test Result

Coefficients $^{\mathbf{a}}$

\begin{tabular}{|c|c|c|c|c|c|}
\hline \multirow[b]{2}{*}{ Model } & \multicolumn{2}{|c|}{$\begin{array}{l}\text { Unstandarized } \\
\text { Coefficients }\end{array}$} & \multirow{2}{*}{ 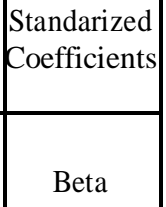 } & \multirow[b]{2}{*}{$\mathrm{t}$} & \multirow[b]{2}{*}{ Sig } \\
\hline & B & $\begin{array}{l}\text { Std. } \\
\text { Error }\end{array}$ & & & \\
\hline 1 (Constant) & 1.795 & .321 & & 5.588 & .000 \\
\hline ROA & -1.157 & .278 & -.510 & -4.157 & .000 \\
\hline SIZE & -.045 & .012 & -.466 & -3.797 & .001 \\
\hline
\end{tabular}

Based on the results of partial testing ( $t$ test) in the table above can be described as follows:

1. Effect of Profitability on Capital Structure

From table 4.13 it can be seen that the value of $t$ calculates profitability that is proxied using ROA (X1) of -4.157 with a significance of $0,000<0.05$. This is in line with the results of statistical tests that compare between $t$ count with $t$ table $(0.025 ; 27)$ is 2.052 , then $t$ count $>t$ table $(4.157>2.052)$. Thus it can be concluded that profitability has a negative effect on capital structure.

\section{Effect of Company Size on Capital Structure}

From table 4.13 , it can be seen that the value of t calculated company size (X2) is -3.779 with a significance of $0.001<0.05$. This is consistent with the results of statistical tests that compare between $t$ count with $t$ table $(0.025 ; 27)$ is 2.052 , then $t$ count $<t$ table $(3.797>2.052)$. Thus it can be concluded that the size of the company negatively affects the capital structure.

\section{Uji F}

Table 2. F Test Result

ANOVA $^{\mathrm{a}}$

\begin{tabular}{|l|r|r|r|l|l|}
\hline & Sum of & & Mean & & \\
Model & Squares & df & Square & F & Sig. \\
\hline Regression & .435 & 2 & .217 & 24.576 & $.000^{\mathrm{b}}$ \\
Residual & .239 & 27 & .009 & & \\
Total & .674 & 29 & & & \\
\hline
\end{tabular}

a. Dependent Variable: DER

b. Predictors: (Constant), SIZE, ROA 
Based on the analysis of the F test in the table above, it can be seen that simultaneously the independent variables have sig $<0.05$ which is 0,000 and $F$ count is 24,576 . By using a $95 \%$ confidence level $=5 \%$, df 1 (number of variables -1$)(3-1)=2$ and df 2 (n-k-1) or 30-2-1 $=27$ ( $\mathrm{n}$ is the number of cases and $\mathrm{k}$ is the number of independent variables), the results obtained for $\mathrm{F}$ table are 3.35. Thus the value of F count is 24.576> F table 3.35. So it can be concluded that the independent variables in this study, namely profitability (X1) and firm size (X2) simultaneously influence the company's capital structure (Y).

\section{Analysis of Multiple Linear Regression}

The results of multiple regression analysis in this study are as follows:

$\mathrm{Y}=1,795-1,157 \mathrm{X} 1-0,045 \mathrm{X} 2+\mu$

The results of the multiple regression equation can be explained as follows:

1. Constants of 1.795 means that if all independent variables are considered constant (worth $0)$ then the capital structure is valued at 1.795 .

2. ROA of $-1,157$ means that if ROA increases by 1 unit while other variables are considered constant, the capital structure will decrease by 1,157 units.

3. SIZE is -0.045 means that if SIZE rises by 1 unit while other variables are considered constant, the capital structure will decrease by 0.045 units.

\section{Discussion}

\section{Effect of Profitability on Structure}

Based on the results of the study, profitability has a negative effect on capital structure. This is consistent with previous research conducted by Rasmiati, Tasman, and Melda (2015) which states that the use of profitability calculated using Return on Asset has a negative effect on capital structure. But it is not in accordance with the research conducted by Widyaningrum (2015) which states that profitability does not affect the capital structure. The results of this study are in line with the grand theory of Pecking Order Theory revealed by Myers \& Maljuf (1984) that companies tend to use as many internal funding sources as possible before deciding to owe, meaning companies that have high returns have a tendency to use funding external or lower debt so that the value of the capital structure is also low.

\section{Effect of Company Size on Capital Structure}

Based on the results of the study it can be concluded that the size of the company negatively affects the capital structure. This is in accordance with previous research conducted by Meisya (2017) which states that company size has a negative effect on capital structure, but not in accordance with the research conducted by Widyaningrum (2015) which states that firm size does not affect the capital structure. This happened because several pharmaceutical companies listed on the Indonesia Stock Exchange had determined that a large portion of earnings were used for company reserves. That way the company has a greater percentage of retained earnings, so it is able to fund its funding needs with internal costs which cause the capital structure is not high. This is also in line with Pecking Order Theory that companies tend to use as many internal funding sources as possible before deciding to owe, meaning 
companies that have high assets are able to maximize assets owned by placing cash held as the main operational source so as to reduce the amount of debt they have.

\section{Effect of Profitability and Company Size on Capital Structure}

The results of this study indicate that the variable profitability and size of the company jointly influence the capital structure. This value indicates that the capital structure of the pharmaceutical sub-sector companies listed on the Indonesia Stock Exchange in 2012-2017 is influenced by variable profitability and firm size as explained by the regression test of this study. The results obtained by the researchers are also in accordance with previous studies conducted by Tasman and Melda (2015) that the profitability and size of influential companies towards capital structure because of the level high returns allow the company to finance most of the funding with funds generated internally, besides that a large amount of assets also allows the company to use its internal funds so as to minimize the use of external funds. But the results of this study are not in accordance with the research conducted by Naibaho (2015) which states that the profitability and size of the company does not affect the capital structure.

\section{Conclusion}

Based on research conducted by researchers, conclusions can be taken as follows:

1. Profitability has a negative effect on the Capital Structure of the pharmaceutical sub-sector companies listed on the Stock Exchange for the period of 2012-2017. This can be proven by the Sig 0,000 value which is smaller than $0.05(0,000<0,05)$ and t-count value $-4,157$ where t count is greater than t table $(4,157<2,052)$.

2. Company size has a negative effect on Capital Structure in pharmaceutical sub-sector companies listed on the Stock Exchange for the period 2012-2017. This is evidenced by the Sig 0.001 value that is smaller than $0.05(0.001<0.05)$ and the value of the $t$ count of 3.779 where $t$ count is greater than $t$ table (3.797> 2.052).

3. Profitability and Company Size affect the Capital Structure of pharmaceutical sub-sector companies listed on the Stock Exchange for the period 2012-2017. This is evidenced by the Sig 0,000 value which is smaller than $0.05(0,000<0,05)$ and the calculated $F$ value of 24,576 where $\mathrm{F}$ count is greater than $\mathrm{F}$ table $(24,576>3,35)$.

\section{Suggestion}

There are suggestions that can be conveyed to the reader in connection with the problems of this research, namely as follows:

\section{For Practitioners}

Based on the results of the study, the company is advised to pay more attention and caution in determining financial decisions that reflect the company's internal financial condition, especially covering the profitability and size of the company in order to have good quality in managing the source of funds. This is important so that companies can be wiser in using internal funding sources and reducing dependence on using external sources of funds so that they can attract investors who want to invest and expect high returns. Then the company is also expected to always provide objective, relevant, and verifiable financial information. 


\section{For Academics}

This study uses capital structure as the dependent variable with Debt to Equity Ratio (DER) as an indicator. For further researchers are advised to measure capital structure using other indicators and can add other variables besides the Return on Assets (ROA) and Company Size ratios which are still rarely examined as variables that are thought to influence capital structure such as asset structure, operating leverage, company growth rate, and so on. Further researchers can also add to the research period for example 10 year and also conduct research in other sub-companies such as food and beverages sector, mining sector, construction and building sub-sectors, and so on.

\section{References}

[1]. Antoni, Chandra, C., dan Susanti, F. (2016). Faktor-Faktor yang Mempengaruhi Struktur Modal Perusahaan Manufaktur di Bursa Efek Indonesia. Jurnal Benefita, [online] Volume1(2). Tersedia di: http://ejournal.kopertis10.or.id/index.php/be nefita [Diakses pada 5 Agustus 2018].

[2]. Brigham F. Eugene dan Joel F. Houston. (2013). Dasar-Dasar Manajemen Keuangan. Edisi kesebelas. Jakarta: Salemba Empat, halaman 189.

[3]. Fahmi,I. (2013). Analisis Laporan Keuangan. Bandung: Alfabeta, halaman 135.

[4]. Fitriati, T., dan Handayani, N. (2016). Pengaruh Struktur Aktiva, Profitabilitas, dan Ukuran Perusahaan terhadap Struktur Modal. Jurnal Ilmu dan Riset Akuntansi, [online] Volume 5(10). Tersedia di: https://core.ac.uk/download/pdf/151519792. pdf [Diakses pada 31 Juli 2018].

[5]. Halim, A. (2015). Auditing: Dasar-Dasar AuditLaporan Keuangan. Edisi Kelima. Yogyakarta : Unit Penerbit dan Percetakan STIM YKPN, halaman 81.

[6]. Hartati, S. (2015). Pengaruh Ukuran Perusahaan, Profitabilitas, Leverage, dan Kepemilikan Institusional terhadap Perataan Laba (Studi pada Perusahaaan Pertambangan yang Terdaftar di Bursa Efek Indonesia periode 2011-2014). Skripsi. Universitas Pasundan.

[7]. Hidayat, R. (2015). Pengaruh Likuiditas, Profitabilitas, Struktur Aktiva dan Ukuran Perusahaan terhadap Struktur Modal pada Perusahaan Manufaktur Sektor Makanan dan Minuman yang Terdaftar di Bursa Efek Indonesia. Skripsi. Universitas Tadulako Palu.

[8]. Kasmir. (2014). Analisis Laporan Keuangan Cetakan ketujuh Jakarta: PT Raja Grafindo Persada, halaman 197.

[9]. Maidah, I. (2016). Profitabilitas, Struktur Aktiva, Ukuran Perusahaan Mempengaruhi Struktur Modal Perusahaan Perdagangan di BEI. Jurnal Ilmu dan Riset Manajemen, [online] Volume 5(7). Tersedia di: https://core.ac.uk/download/pdf/151520397. pdf [Diakses pada 7 Agustus 2018].

[10]. Meisya, L. (2017). Pengaruh Profitabilitas, Ukuran Perusahaan dan Pertumbuhan Penjualan terhadap Struktur Modal (Studi Emipiris pada Perusahaan Manufaktur yang Terdaftar di Bursa Efek Indonesia Periode 2012-2015). Skripsi. Universitas Lampung.

[11]. Munawir. (2014). Analisis Laporan Keuangan.

[12]. Naibaho, A. (2015). Pengaruh Profitabilitas, Pertumbuhan Penjualan, Struktur Aktiva Dan Ukuran Perusahaan Terhadap Struktur Modal (Studi Kasus pada Perusahaan Property And Real Estate yang Terdaftar di Bei Tahun 2011-2013). Jurnal Administrasi Bisnis, [online] Volume 28(01). Tersedia di: http://administrasibisnis.studentjournal.ub.ac .id/index.php/jab/article/view/1138 [Diakses pada 15 Maret 2019].

[13]. Rahmiati, Tasman, A., dan Melda, Y. (2015). Pengaruh Profitabilitas dan Ukuran Perusahaan terhadap Struktur Modal Perusahaan Property dan Real Estate yang Terdaftar di Bursa Efek Indonesia Tahun 2010-2013. Di dalam: Seminar Nasional Ekonomi Manajemen Dan Akuntansi (SNEMA) Fakultas Ekonomi Universitas Negeri Padang. [online] Padang: SNEMA. Tersedia di: http://fe.unp.ac.id/sites/default/files/unggahan/24.\%20Rahmiati\%2C\%20Abel\%20Tasma n\%2C\%20Yulira\%20Melda\%20\%28hal\%20 325-333\%29_0.pdf [Diakses pada 7 Agustus 2018].

[14]. Riyanto, A. (2013). Statistik Deskriptif. Yogyakarta:Nuha Medika.

[15]. Sjahrial, D. dan Purba, D. (2013). Analisis Laporan Keuangan. Jakarta: Mitra Wacana Media, halaman 37. 
[16]. Sugiarto. (2009). Struktur Modal ,Struktur Kepemilikan Perusahaan, Permasalahan Keagenan dan Informasi Asimetri. Yogyakarta: Graha Ilmu.

[17]. Widyaningrum, Y. (2015). Pengaruh Profitabilitas, Struktur Aktiva, dan Ukuran Perusahaan terhadap Struktur Modal (Studi Empiris pada Perusahaan Manufaktur yang Terdaftar di Bursa Efek Indonesia Periode 2010-2013). Skripsi. Universitas Negeri Yogyakarta. 